\title{
Yenilikçi Materyal Tasarlamanın Sınıf Öğretmeni Adaylarının Yenilikçilik Düzeylerine Etkisi
}

\author{
Gamze YAVUZ KONOKMAN, Yrd. Doç. Dr., Bartın Üniversitesi Eğitim Fakültesi, yavuz.gamze@hotmail.com \\ Gürol YOKUŞ, Arş.Gör., Mersin Üniversitesi Eğitim Fakültesi, gurolyokus@gmail.com \\ Tuğba YANPAR YELKEN, Prof. Dr., Mersin Üniversitesi Eğitim Fakültesi, tyanpar@gmail.com
}

Öz: Yenilikçi materyal tasarlamanın sınıf öğretmeni adaylarının yenilikçilik düzeylerine etkisini ve yenilikçi materyal tasarlama sürecinden sonra öğretmen adaylarının yenilikçilik algısını ortaya çıkarmak amacıyla gerçekleştirilen bu çalışma durum çalışması olarak tasarlanmıştır. Araştırma grubunu 20132014 öğretim yılında Mersin Üniversitesi Eğitim Fakültesi Sınıf Öğretmenliği Programında 3. sınıfta öğrenim gören 27 öğretmen adayı oluşturmaktadır. Yenilikçi materyal tasarlama süreci öncesi ve sonrasında öğretmen adaylarına bireysel yenilikçilik ölçeği ve yenilikçilik algısı anketi uygulanmıştır. Ayrıca uygulama sürecinde öğretmen adaylarının yenilikçi materyal tasarlama sürecine ilişkin günlük tutmaları istenmiştir. Elde edilen nitel verilerin analizinde Nvivo 8 programı yardımıyla içerik analizi yapılmıştır. Nicel veriler, betimsel istatistikler, ilişkili ve ilişkisiz örneklemler için t-testi analiz teknikleriyle çözümlenmiştir. Çalışma sonunda, yenilikçi materyal tasarlayan sınıf öğretmeni adaylarının yenilikçilik düzeylerinde artışın olduğu sonucuna ulaşılmıştır. Ayrıca öğretmen adaylarının eğitimde yenilikçilik, yenilikçi öğretmenin özellikleri ve yenilikçi materyal geliştirme konusunda algılarının oluşturulduğu görülmektedir. Yenilikçi materyal geliştirme sürecine ilişkin öğretmen adaylarının olumlu görüşleri çalışma sonuçlarındandır.

Anahtar Kelimeler: materyal geliştirme, yenilikçilik, öğretmen adayı

\section{The Effect of Designing Innovative Material on the Elementary School Pre-service Teachers' Innovativeness}

\begin{abstract}
The study, having been carried out to determine the effects of designing innovative material on the elementary school prospective teachers' innovativeness and present their perceptions on innovativeness after the process of designing innovative material, was designed as a case study. Research group consisted of 27 third grade prospective teachers educated at Elementary School Teaching Program at Mersin University during 2013-2014 academic year. Individual innovativeness scale and innovativeness perception questionaire were applied to the prospective teachers before and after the process of designing innovative materials. Moreover, they were desired to keep diaries about the design of innovative materials. Content analysis was done via Nvivo 8 program for the analysis of qualitative data. Quantitative data was analyzed through such techniques as descriptive statictics, $t$-test for dependent and independent samples. As a result of the study, an increase in the innovativeness level of the elementary school prospective teachers desinging innovative materials was dedued. Furthermore, it was observed that the prospective teachers' perceptions on innovativeness in education, the properties of innovative teacher, innovative material design existed. Moreover, the prospective teachers' positive views on design of innovative materials was among the results of the study.
\end{abstract}

Key Words: material design, innovativeness, prospective teacher 


\section{GíRiş}

Post-modern dönemi yaşayan küresel dünyada öğretmen yetiştirme meselesinin, bilimsel araştırmalar sonucunda ortaya konulmuş çağdaş eğitim sistemine uygun belirli standartlara göre ele alınması gerekmektedir. Yılmaz'ın (2007) belirttiği gibi “çağdaş eğitim sisteminin hedefi; bilgiye ulaşma yollarını araştıran, öğrendiği bilgiyi nerede ve nasıl kullanacağını bilen, eleştirel düşünceye sahip bireyler yetiştirmektir". Konjonktürel açıdan 21. yüzyılın tüm sosyolojik, ekonomik ve politik gerçekliklerinden etkilenen eğitim sistemi, endüstri devriminin ya da ilk dönem bilgi çağının ihtiyaç duyduğu birey tipine değil, bilgi ve iletişim kavramlarına odaklı "bilişim" çağının ihtiyaç duyduğu birey tipine yönelmiştir. Bu noktadan hareketle günümüz dünyasında problem çözme, eleştirel düşünme, işbirliği yapabilme, bilgi ve iletişim teknolojilerini etkili kullanabilme, yenilikçilik (inovasyon) gibi özellikler bireyleri vazgeçilmez kılmayan ancak sahip olmaları beklenen özellikler olarak karşımıza çıkmaktadır (Partnership for 21st Century Skills, 2005).

Kılıçer (2011) günümüzde bilgi miktarındaki artışa paralel olarak, yenilik miktarının da artığını ve yeniliklere verilen tepki sürelerinin kısaldığını belirtmiş ve bu durumun bireyin yenilikçi olmasını zorunlu kıldığına değinmiştir. Ona göre, yenilikçilik eskiden bireyi farklı kılan bir özellik iken, günümüzde tek başına fark yaratmayan ama fark yaratmak için bir önkoşul olan mesele haline gelmiştir. Eğitimde inovasyon konulu 2. Uluslararası Eğitim Forumunda Elçi (2011) yenilikçiliğin (inovasyonun) ekonomik kalkınmanın itici gücü olduğunu; istihdam ve refahın ancak yenilikçilik (inovasyon) sayesinde artabileceğini, inovasyonun temelini çok sayıda ve birden fazla fikir, birbirinden farklı alternatifler ve mevcut bilgiden (bilinenden) uzaklaşmanın oluşturduğunu ifade etmiştir. Dünya Ekonomik Forumu'nun (WEF) 2014-2015 Küresel Rekabet Endeksi raporunda da inovasyon yeteneğiyle ülkelerin rekabetçilikleri arasındaki doğru bir orantının bulunduğu ve bunların birbirleriyle bağlantılı olduğu ifade edilmiştir. Inovasyon kapasitesinin direkt olarak, bilimsel araştırma kurumlarının niteliği, şirketler kesiminin ar-ge harcamaları, ar-ge için üniversite-sanayi işbirliği, ileri teknolojiler için kamunun satın alma politikaları, bilim insanlarının ve mühendislerin varlığı, patentler, fikri mülkiyet haklarının korunması değişkenlerinden oluştuğu belirtilmiştir.

Bu durumda ülkelerin yenilikçi bireyler yetiştirme hedefini gerçekleştirebilmeleri için eğitim programlarını yeniden yapılandırmaları ve yenilikçi toplumun oluşturulması için yenilikçilik konusunda çalışmalar gerçekleştirmeleri önem taşımaktadır. Bunu farkına varan ülkeler, yenilikçiliği karar alma mekanizmalarında odak noktası haline getirmişlerdir. Örneğin, yenilikçiliği geliştirme amaçlı devlet teşvikini hükümetin stratejik hedefleri arasına alan ülkeler arasında İngiltere, ABD ve Almanya ön plana çıkmaktadır. Bu devletlerde yenilikçilik stratejisi ile ilgili çeşitli kurumsal organizasyonlar kurulmuştur. Mesela, Almanya sanayi açısından yenilikçiliğin temeli olarak benimsediği AR-GE birimlerini uygulamaya geçiren ilk ülke konumundadır (Ersoy ve Şengül, 2008). ABD'de de bireylerin üniversite eğitimine kadar sahip olmaları beklenen 21. yy becerilerinin tanımlanmasına ve bu becerilerin kazandırılmasına ilişkin çalışmalar gerçekleştirilmiştir (Partnership for 21st Century Skills, 2005). Ülkemizde ise, gerçekleştirilen projelerle bireylerin inovasyon kültürüne sahip, girişimci olmalarını sağlamak amaçlanmıştır. Örneğin, 2005 yılında Dünya Bankası desteği ile gerçekleştirilen "Eski köye yeni adet getirin!" (EKIN) projesi kapsamında ilköğretim öğrencilerinin inovasyon kültürüne sahip ve girişimci bireyler olarak yetişmeleri amaçlanmıştır. Bu kapsamda ilköğretim beşinci sınıf öğrencilerinden ve öğretmenlerinden katılımcılar belirlenerek inovasyon konusunda eğitim verilmiş, başarılı girişimcilerin inovasyon öyküleri aktarılmış ve çocukların sanal şirketler aracılığıyla inovasyon fikirleri üretmeleri teşvik edilmiştir (Elçi, 2005). 21. yüzyılda bilgi miktarındaki hızlı değişimin varlığı ve bireylerin bilgiye ulaşma ve bilgiyi en etkili şekilde 
kullanabilmesinin bir gerekliliğe dönüşmesi nedeniyle eğitim kurumlarında bireyleri girişimci kılan ve yenilik üretmeye teşvik eden uygulamaların artırılması ihtiyacı doğmuştur.

Bilgi ve teknoloji çağında bilgi ve yenilik miktarındaki hızlı artış, bireylerin yeniliklere direnç göstermeyerek yenilikleri kabullenen, yenilikçi kimliğe sahip olmasını gerektirmektedir. Yenilikçilik (inovasyon) kavramının özünde ihtiyaçların daha iyi karşılanması amacıyla bir değişim başlatma çabası yer almaktadır. Yenilikçiliğin amacı daha önce çözülmemiş sorunları çözmek, daha önce karşılanmayan ihtiyaçlara cevap vermek, var olan pek çok ürün ve hizmeti daha güzel, daha kullanışlı, daha çok insanın işine yarayacak şekilde geliştirmek olarak açıklanabilir. Alan yazın incelendiğinde ise, yenilikçilik kavramının "yeniliklere gösterilen tepki" (Goldsmith ve Foxall, 2003), "değişime karşı istekli olma" (Hurt, Joseph ve Cook, 1977), "orijinal, yeni ve değerli bir ürün, bir üretim süreci, ya da bir hizmet yaratmak için bilginin sentezi, kombinasyonu ya da somutlaşması" (Luecke, 2008), "yeni veya iyileştirilmiş ürün, hizmet, sistem veya programları geliştirmek ve bunları etkin hale sokmak için yürütülen tüm süreçler" (Ersoy ve Şengül, 2008); "yeni mal ve hizmetlerin işletmeye yarar sağlayacak şekilde bir ürün ve/veya hizmete dönüştürülmesi süreci" (Aksay, 2011) ve "örgüt içerisindeki mevcut uygulamaların dışındaki, her türlü teknik, örgütsel, ekonomik ve yönetimsel değişiklikler" (Fidan, 2015) olarak tanımlandığı görülmektedir.

Kılıçer (2011) yenilikçiliğin "yeni olana pozitif tepkiyi" ve "yenilikten yana olmayı" kapsadığını vurgulamaktadır. Yenilikçilik tanımlanırken üzerinde durulması gereken temel kavramlar "süreklilik, dinamiklik ve köklü değişimler" olarak ele alınmaktadır (Demirel ve Seçkin, 2008). Bireyi yenilikçi olması, yenilikçi olmayı engelleyen faktörlerin üstesinden gelinmesiyle sağlanabilir. Bireyin yenilikçi olmasını engelleyen bireysel, kurumsal ve toplumsal engellerin olduğu belirtilmektedir. Bireysel engeller arasından bireyin bilgi düzeyi, güdülenme düzeyi, iletişim ve empati becerisi, yenilik ve değişeme yönelik inancı, tutumu, risk alma düzeyi ve eğilimi, kurumsal engeller arasında bireyin eğitim gördüğü kurumun altyapısı, teknolojiye erişim miktarı, eğitim programlarının yenilikçiliğe uygunluğu, eğiticilerin nitelikleri, kurumun vizyonu, destek ve liderlik özelliği kurumsal engelleri, toplumsal engeller arasında ise bireyin içinde bulunduğu topluma ait değerler, normlar, politikalar ve aile yapısı yer almaktadır (Kılıçer, 2011). Yenilikçiliği engelleyen etmenler arasında (özellikle ilköğretim okullarında yeniliklerin) yönetsel yapı, motivasyon eksikliği, iletişim/bilgi yetersizliği, kaynak yetersizliği, kurumsal kültür yetersizliği ve değişim liderliği yetersizliği gibi kurumsal engellerin olduğunu belirtilmektedir (Çelik, 2006).

Basadur ve Gelade (2006) yenilikçilik sürecinde bilgi yönetiminin rolüne odaklanmış ve yenilikçiliği "oluşturma, kavramsallaştırma, optimize etme ve uygulamaya koyma" boyutları altında incelemiştir. Oluşturma boyutunda, yenilikçiliğin "imkanları hayal etmek, sorgulamak, yeni sorunları ve fırsatları hissetmek, farklı perspektiflerden göz atmak ve doğrudan tecrübeyle bilgi toplamak" olduğunu; kavramsallaştırma boyutunda "doğrudan tecrübeler yerine, soyut düşünme ile kavrayış, fikirleri bir araya getirmek, sorunları tanımlamada bakış açıları geliştirmek ve teorik modeller üretmek"; optimize etme boyutunda "bireylerin değerlendirme sonucunda birleşmeye ve sonuca gittiği, soyut fikirlerden pratik çözümler geliştirme, fikirleri denemeden önce zihinsel olarak test etme, optimal çözümler arama", uygulamaya koyma boyutunda ise "işleri yürütmek için bir an önce harekete geçmek, ilerlemek için her şeyin tam olmasını aramaktansa yola koyulup değişen durumlara hızlıca adapte olmayı" içerdiği ifade etmiştir. Wolpert (2003) ise, yenilikçiliği sadece bir iyileştirme ve optimize etme süreci olarak görmenin yanıltıcı olduğunu, yenilikçiliğin yeni ortaya çıkan ve yapı-bozumuna izin veren teknolojileri kullanıp tamamıyla yeni fırsatların ortaya konulması olarak açıklamıştır.

Bireylerin girişimcilik düzeylerini etkileyen kalıtımsal ve çevresel değişkenler bulunmaktadır. Örneğin, Erdal (2001) bireylerin girişimcilik eğilimleri ile babanın sabit maaş 
karşılığı ya da kendi başına bağımsız çalışması arasında anlamlı bir ilişki bulunmadığı sonucunu ortaya koymuştur. Diğer bir değişken olarak ebeveynin eğitim düzeyi ile öğrencilerin girişimcilik eğilimi arasında doğru orantı bulunduğu saptanmıştır. Mesleki açıdan öğretmenliği seçen bireylerin, olumlu ve etkili bir öğrenme ortamı geliştirmek için, özellikle materyal geliştirmede yenilikçilik düzeylerinin yüksek olması beklenmektedir; çünkü materyal geliştirme içerisinde çok önemli becerilerin yer aldığı bir süreci barındırmaktadır. Bu önemli beceriler arasında en ön plana çıkan öge öğrenme materyallerinin kalitesinden ziyade ne tür etkili yollarla kullanıldığıdır. Cohen ve Ball'un (2000) dediği gibi materyal geliştirme hakkında öne çıkan ilk şey maliyeti (pahalılığı) ve kalitesi (neyden yapıldığı) değil, yeniliklerin pek çok öğrenme unsurunun (uygulayıcılar, öğrenciler ve ortam) ihtiyaçları doğrultusunda gerçekleştirilmiş olmasıdır. Cohen ve Ball materyal geliştirmede yeniliklerin (inovasyonların) neden başarısız olduğuna da değinmiş ve bunun arkasında "inovasyonların gerçek yaşamı dikkate almadığı, sınıf disiplini, okul organizasyonu ve öğretim açısından uygunsuzluğu" gibi faktörlerin bulunduğuna dikkat çekmiştir. Tella ve Kirsi (1999) yenilikçilik kavramını farklı ıraksak düşünme açılarından ele almıştır. Yenilikçiliği ele alırken "yenilik olarak, ürün olarak, değişim olarak, eylem olarak, süreç olarak ve amaç olarak yenilikçilik" boyutları açısından incelemiştir. Materyal geliştirme ve yenilikçilik arasındaki ilişkide ortaya çıkan en temel sorunu "bazı yayınevlerinin finansal sebeplerle radikal (kökten değişim gösteren) yeni materyaller yerine geleneksel materyalleri tercih etmesi" olarak nitelemiş ve yayınevlerinin program geliştirme uzmanlarına karışmaması gerektiğini ve öncelikle pedagojik yarar meselesini düşünmelerine vurgu yapmıştır. Ayrıca, Tella ve Kirsi (1999) yenilikçilik etkinliklerine katılan öğretmenlerin devlet tarafından ödüllendirilmesi gerektiğini ifade etmiştir. Onlara göre yenilikçiliğin gelişmesi ve yaygınlaşmasında ilk şart, sınıf içerisinde öğretim etkinliklerinin uygulayıcıları olan öğretmenlerin istekliliği ve desteğidir.

Ülkemizde inceleme yapan uzmanlar, okul dönemindeki bireylerin yenilikçi olma düzeylerinin düşük olduğunu ve yenilikçi bireyler yetiştirmek için eğitime daha çok yatırım yapılması gerekliliğini belirtmektedir (Romer, 2007). Elçi (2011) yaptığı araştırmada, yenilikçi (inovatif) fikirler üretme açısından ilköğretim düzeyindeki öğrencilerin tamamının inovatif fikirler geliştirdiklerini, lise düzeyinde öğrencilerin \%7'sinin, üniversite düzeyindeki öğrencilerin $\% 12$ 'sinin hiç fikir üretmediklerini belirtmektedir. Kısacası eğitim seviyesindeki yükselmeye rağmen bireylerin inovatif fikirler üretme açısından sorun yaşadıkları gözlenmektedir. Eğitimle bireylere yenilikçi birey olma ve yenilik üretme becerilerin kazandırılması amaçlanırken, bu hedefin gerçekleştirilmesinin kolay olmadığı görülmektedir. Bu durumda, eğitim sisteminin yeniliklere direnç göstermeyen, yenilikleri kabullenen, yeni fikirler üreten ve yenilikçi bireyler yetiştirme açısından değerlendirilmesi ve geliştirilmesi gerekmektedir. Bu nedenle, öncelikle öğretmenlerden yenilikçi kimliğe sahip olmaları ve yenilikçi bireyler yetiştirme konusunda gerekli bilgi ve becerilerilere sahip olmaları beklenmektedir. Ancak Lope Pihie ve Bagheri (2011), ortaöğretim öğretmenlerinin yenilik (inovasyon) üretme davranışı konusunda düşük puanlara sahip olduklarını belirtmektedir.

Erdoğan ve Güneş (2013) Eğitim Fakültesindeki öğrencilerin yenilikçilik düzeyleri ve değişime hazırbulunuşlukları üzerine yaptığı çalışmada, öğretmen adaylarının sadece yüzde 4,4'ünün yenilikçi olduğunu, yüzde $34,2^{\prime}$ sinin erken benimseyenler, yüzde $49,5^{\prime}$ inin erken çoğunluk, yüzde $9,1^{\prime}$ nin geç çoğunluk ve yüzde $2,8^{\prime}$ nin ise ağır hareket edenler olduğunu ortaya koymuşlardır. Ayrıca bu çalışmada bireysel yenilikçilik ile değişim hazırbulunuşluğu arasında .70 anlamlı ilişki olduğu saptanmıştır. Özgür ve Summak (2014) ise sınıf öğretmenleriyle yaptığı araştırmada, öğretmen adaylarının yüzde 43,3'ünün Yenilikçi ve Öncü kategorisinde olduğunu, yüzde 41,1'inin Sorgulayıcı, yüzde 14,6'sının Kuşkucu, yüzde 1'inin Gelenekçi olduğu bulgusuna ulaşmışlardır. Çoklar (2012) eğitim kurumlarındaki yöneticilerle gerçekleştirdiği çalışmasında yöneticilerin kendilerini "erken benimseyenler" olarak nitelediklerini, mesleki kıdemin bireysel 
yenilikçilik açısından önemli olmadığını, 10 seneden daha fazla ve daha az tecrübesi olanlar arasında anlamlı bir farklılık bulunmadığını ortaya koymuştur. Ayrıca bu çalışmada interneti her gün kullanan yöneticilerin, haftada/ayda birkaç kez kullanan yöneticilere kıyasla daha yenilikçi oldukları saptanmıştır. Çuhadar, Bülbül ve Ilgaz (2013) ise öğretmen adaylarıyla çalışma yapmış ve öğretmen adaylarının kendilerini "erken çoğunluk" olarak nitelediklerini, bireysel yenilikçilik düzeyleri ile tekno-pedagojik yeterlilikleri arasında cinsiyete göre anlamlı farklılık bulunmadığını belirtmişlerdir. Çalışmanın bulguları, öğretmen adaylarının bireysel yenilikçilikleri ile tekno-pedagojik yeterlilikleri arasında orta düzeyde pozitif anlamlı ilişki olduğunu göstermektedir.

Yenilikçi toplumun şekillendirilmesinde önemli rol üstlenen öğretmenlerin ve öğrencilerin yenilikçi olmasını sağlamak için eğitim politikalarının ve eğitim sisteminin yeniden yapılandırılması gerekmektedir. Elçi (2011) eğitim sisteminin yeniden yapılandırılmasında yenilik, girişimcilik ve yaratıcılık kültürünün bireylere erken yaşlarda kazandırılması ve tüm eğitim dönemlerinde üzerinde durulması gerektiğine değinmektedir. Bu nedenle eğitim sisteminin, yenilikçi bireylerin yetiştirilmesini sağlayıcı biçimde yapılandırılması, program değerlendirme çalışmalarının yenilikçilik boyutuna önem verilmesi ve tasarlanan öğretim programlarının yenilikçiliği geliştirmeye dayalı olması büyük önem taşımaktadır.

Yenilikçilik ile eğitim arasındaki karşılıklı bir belirleyiciliğin bulunması, bu iki kavramın öğretim ortamlarında öğretimin kalitesini artırmak üzere yeniden düzenlenmesini gerektirmektedir. Eğitim hizmetinin uygulayıcıları olacak öğretmen adaylarının ilk başta kendilerinin eğitim alanındaki yeniliklere direnç göstermemesi, yenilikleri kabullenmeye istekli olması, kolay ve kısa sürede yenilikleri kabullenmeleri, yani yenilikçi kimliğe sahip olmaları önemlidir. Bu nedenle bu çalışmada geleceğin öğretmeni, çocukların ve yetişkinlerin rol modeli olacağı düşünülen öğretmen adaylarının yenilikçi materyal geliştirmeleri sağlanarak yenilikçi kimlik kazanmalarını sağlamak amaçlanmıştır. Bu amaç doğrultusunda gerçekleştirilen çalışmada aşağıdaki sorulara yanıt aranmıştır:

1. Sınıf öğretmeni adaylarının yenilikçi materyal tasarlama süreci sonrasında yenilikçilik düzeylerine ilişkin algıları nasıldır?

1.1. Sınıf öğretmeni adaylarının yenilikçi materyal tasarlama süreci öncesi ve sonrası yenilikçilik düzeyleri istatistiksel olarak anlamlı bir farklılık göstermekte midir?

1.2. Sınıf öğretmeni adaylarının yenilikçi materyal tasarlama süreci sonrasında yenilikçilik düzeyleri cinsiyete göre anlamlı bir farklılık göstermekte midir?

2. Yenilikçi materyal tasarlama süreci öncesinde ve sonrasında sınıf öğretmeni adaylarının yenilikçilik kavramına ilişkin algıları nasııdır?

\section{YÖNTEM}

\section{1. Çalışma Grubu}

Bu çalışma nitel araştırma yöntemlerinden durum çalışması (case study) deseni ile gerçekleştirilmiştir. Bu desende veriler, çalışmanın araştırdığı durumu tecrübe eden ve bu durumu yansıtabilecek katılımcılardan toplanır. Bu araştırma desenini tercih eden araştırmacılar, bir veya birkaç duruma odaklanıp ilgili durumun etkilediği ve etkilendiği değişkenler üzerine derinlemesine araştırma yaparlar (Yıldırım ve Şimşek, 2006). Durum çalışması deseninde en kritik mesele durumların seçimidir. Seçilen durumların, ilgili olay ve olguları temsil etme gücü tam olmalıdır (Davey, 1991). Durum çalışmasında, çeşitli veri toplama araçları kullanılarak etkinlik, olay, eylem, süreç ya da bireyler gibi özel belirlenmiş bir durum derinlemesine keşfedilir ve bütüncül analizi yapılır (McMillan ve Schumacher, 2010). 


\section{2. Çalışma Grubu}

Araştırma grubunu 2013-2014 öğretim yılında Mersin Üniversitesi Eğitim Fakültesi Sınıf Öğretmenliği Programında 3. sınıfta öğrenim gören 27 öğretmen adayı oluşturmaktadır. Çalışmaya katılan öğretmen adaylarının 17'si $(\% 62,96)$ kadın, 10'u $(\% 37,04)$ erkektir. İşbirlikli öğrenme yaklaşımına uygun bir grup oluşturmak için öncelikle öğretmen adaylarının 2013-2014 öğretim yılında "Öğretim İlke ve Yöntemleri" dersi sınav puanlarının aritmetik ortalamaları dikkate alınmış ve öğretmen adayları başarı sırasına göre sıralanmıştır. Öğrencilerin sıralandığı liste beşe bölünerek her bölümden bir öğrenci seçilerek 5 ya da 6'şar kişilik gruplar oluşturulmuştur. Çalışma 12 hafta süren Öğretim Teknolojileri ve Materyal Tasarımı dersinde gerçekleştirilmiştir. Öğretim teknolojileri ve materyal tasarımı dersinin amacı öğretmen adaylarının öğretim hedeflerine uygun öğretim materyali hazırlama ilkeleri doğrultusunda öğretim materyali tasarlamalarını, hazırlamalarını ve uygulamalarını sağlamaktır. Öğretmen adaylarına yenilikçilik bakış açısıyla öğretim materyali tasarlamaları için olanakların sağlandığı bu çalışmanın öğretim teknolojileri ve materyal tasarımı dersinin amacına hizmet ettiği görülmektedir.

\section{3. İşlem}

Çalışma 2013-2014 öğretim yılında bahar yarıyılında Mersin Üniversitesi sınıf öğretmenliği programında yer alan "Öğretim Teknolojileri ve Materyal Tasarımı" dersinde gerçekleştirilmiştir. Öğretim teknolojileri ve Materyal Tasarımı dersi, öğretmen yetiştiren kurumlarda 2 saat teorik 2 saat uygulamalı olarak işlenen 3 kredilik bir derstir. Dersin haftalara göre tasarımı Tablo 1'de sunulmuştur.

Tablo 1.

Zaman İşlem

1. Hafta

Bireysel yenilikçilik ölçeğinin uygulanması, öğretmen adaylarının yenilikçiliğe ilişkin algılarının belirlenmesi amacıyla yenilikçiliğe ilişkin algı anketinin uygulanması, grupların oluşturulması

2. Hafta Uzman tarafından yenilikçilik (inovasyon) eğitiminin verilmesi

3. Hafta Materyal hazırlamada dikkat edilecek hususlara ve materyal hazırlama ilkelerine değinilmesi, öğretim materyali örneklerinin incelenmesi

4. ve 5. hafta Yenilikçi çalışma yaprağı geliştirilmesi ve yenilikçi çalışma yaprağı geliştirme sürecine ilişkin günlükler yardımıyla görüşlerin alınması

6. ve 7. Hafta Yenilikçi kavram haritası geliştirilmesi ve yenilikçi kavram haritası geliştirme sürecine ilişkin günlükler yardımıyla görüşlerin alınması

8. ve 9. Hafta Yenilikçi üç boyutlu materyal geliştirilmesi ve günlükler yardımıyla yenilikçi üç boyutlu materyal geliştirme sürecine ilişkin görüşlerin alınması

10. Hafta Bireysel yenilikçilik ölçeğinin uygulanması, öğretmen adaylarının yenilikçiliğe ilişkin algılarının belirlenmesi amacıyla yenilikçiliğe ilişkin algı anketinin uygulanması

11. Hafta Yenilikçi materyallerin öğretmen adayları tarafından tanıtılması ve 3 uzman tarafından değerlendirilmesi

Öğretim teknolojileri materyal tasarımı konusunda uzman bir öğretim üyesi tarafından yenilikçilik (inovasyon) eğitimi verilmiştir. Eğitim kapsamında öğretmen adaylarına yenilikçiliğin ne olduğu, yenilikçilik (inovasyon) çeşitlerinin neler olduğu açıklanmış, Türkiye'den ve dünyadan inovasyon örnekleri sunulmuştur. Eğitimde yenilikçiliğin (inovasyon) nasıl olacağına odaklanılarak, eğitimde yenilikçi materyallerin nasıl olması gerektiğine ilişkin fikirler üretilmiştir. Eğitim sürecinde tartışma yöntemi ve beyin fırtınası tekniği kullanılmıştır.

Yenilikçilik eğitiminden sonra öğretmen adaylarından grup olarak yenilikçi materyal tasarlamaları istenmiştir. Eğitimde kullanımı yaygın olan kavram haritası, çalışma yaprağı ve 3 
boyutlu öğretim materyallerin yenilikçi (inovatif) materyaller olarak tasarlanması istenmiştir. Her materyal tasarımı sürecinden sonra öğretmen adaylarının yenilikçi materyal geliştirme süreçlerini, yenilikçi materyal geliştirme sürecinde hoşlarına giden ve gitmeyen yönlerin neler olduğunu, geliştirdikleri materyallerin yenilikçi olma düzeyine ilişkin görüşlerini belirtmeleri amaçlanmıştır. Ayrıca öğretmen adaylarının yenilikçilik eğitimi ve yenilikçi materyal tasarımı sürecinden önce ve sonra yenilikçilik kavramına ilişkin algıları belirlenmiştir. Araştırma sürecine ilişkin genel bilgiler Şekil 1'de sunulmuştur.

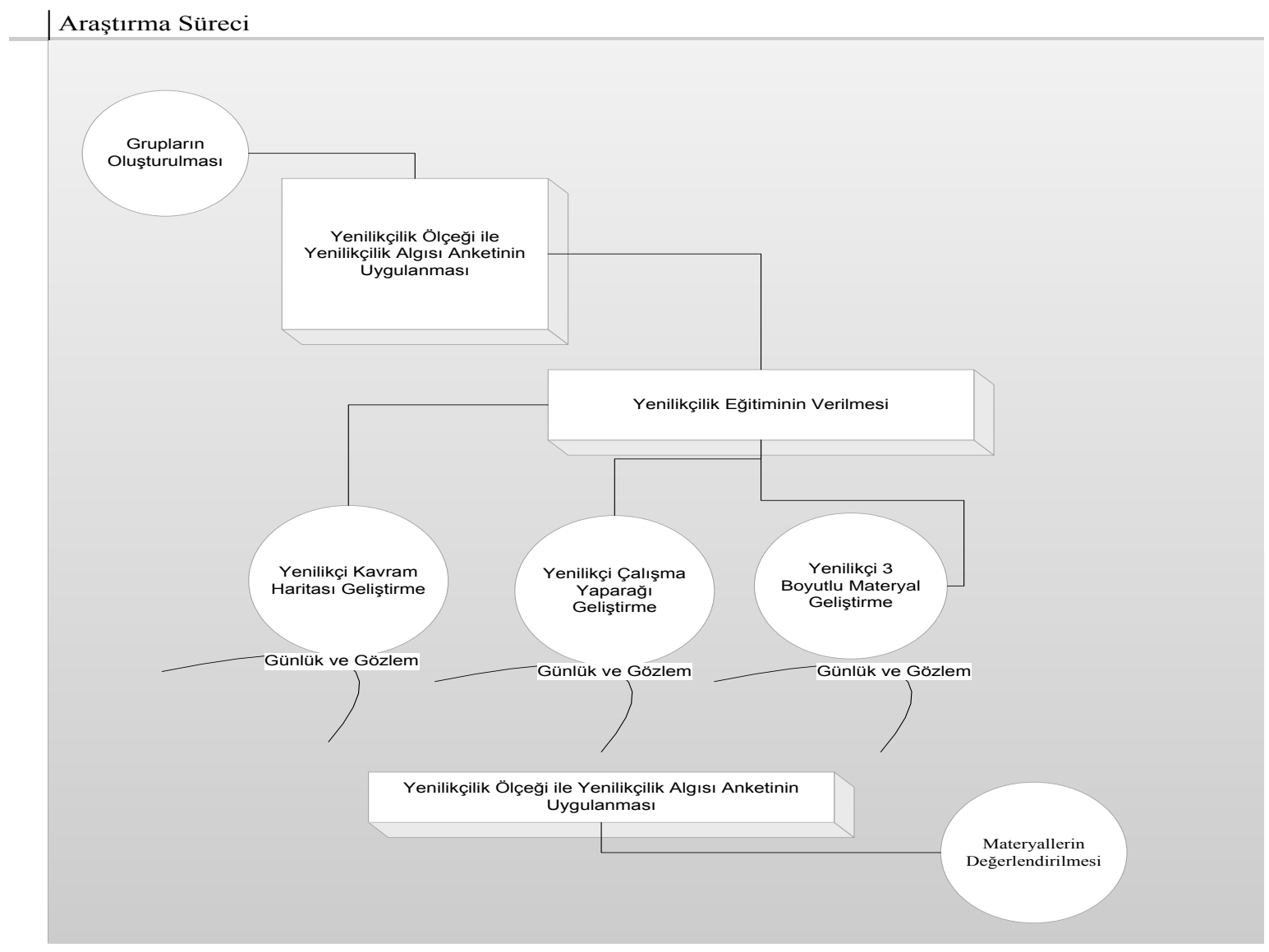

\subsection{Veri Toplama Araçları}

Bireysel yenilikçilik ölçeği. Bireylerin genel anlamda yenilikçiliğini değerlendirebilmek amacıyla Hurt, Joseph ve Cook (1977) tarafından geliştirilen Kılıçer ve Odabaşı (2010) tarafından Türkçe'ye uyarlanan bireysel yenilikçilik ölçeği 20 maddeden oluşan 4 faktörlü bir ölçme aracıdır. Ölçek maddelerinin 12'si pozitif $(1,2,3,5,8,9,11,12,14,16,18$. ve 19. maddeler), 8'i negatif maddelerden $(4,6,7,10,13,15,17$. ve 20 . maddeler) oluşmaktadır. Ölçek yardımıyla yenilikçilik puanı; pozitif maddelerden alınan toplam puandan negatif maddelerden alınan toplam puanın çıkarılmasıyla elde edilen puana 42 puan eklenmesiyle hesaplanmaktadır. Ölçekten alınabilecek en düşük puan 14, en yüksek ise 94 'tür. Ölçekten elde edilen puanlara göre bireyler yenilikçilik açısından sınıflandırılmaktadır. Ölçekten bireyin aldığı puan 80 puanın üstünde ise "Yenilikçi", 69 ve 80 puan arasında ise "Öncü", 57 ve 68 puan arasında ise "Sorgulayıcı", 46 ve 56 puan arasında ise "Kuşkucu", 46 puan altında ise "Gelenekçi" olarak sınıflandırılmaktadır. Ayrıca ölçek yardımıyla hesaplanan puana göre genel olarak bireylerin yenilikçilik düzeylerine ilişkin de değerlendirme yapılabilmektedir. Bu değerlendirmeye göre, 68 üstü puan alan bireyler oldukça yenilikçi olarak değerlendirilirken, 64 
altı puan alan bireyler yenilikçilikte düşük olarak yorumlanmaktadır. Ölçek faktörleri "Değişime direnç", "Fikir önderliği", "Deneyime açıklık" ve "Risk alma" olarak adlandırılmıştır. Değişime direnç faktörünün özdeğeri 3.334, açıkladığı varyans 16.668; ikinci faktörün özdeğeri 2.721, açıkladığı varyans \%13.606, üçüncü faktörün özdeğeri 2.594 , açıkladığı varyans \%12.970 ve dördüncü faktörün özdeğeri 1.855, açıkladığı varyans \%9.277 olarak bulunmuştur. Açımlayıcı faktör analizi sonuçlarına göre, dört faktörün değişkene ilişkin açıkladıkları toplam varyansın \%52.521 olduğu görülmektedir. Ölçeğin tamamına ilişkin güvenirlik katsayısı .82, "Değişime direnç" boyutuna ilişkin güvenirlik katsayısı .81, "Fikir önderliği" boyutuna ilişkin güvenirlik katsayısı .73, "Deneyime açıklık" boyutuna ilişkin güvenirlik katsayısı .77 ve son olarak "Risk alma" boyutuna ilişkin güvenirlik katsayısı .62 olarak bulunmuştur. Tüm ölçeğe ilişkin test tekrar test güvenirliği .87 'dir. Bu bulgular ölçeğin yenilikçilik konusuyla ilgili olan akademik çalışmalarda kullanılabilir, geçerli ve güvenilir bir ölçme aracı olduğunu göstermektedir.

Yenilikçilik algısı anketi. Yenilikçi materyal geliştirme süreci sonrasında öğretmen adaylarının yenilikçilik kavramına ilişkin algılarının belirlenmesinde kullanılan yenilikçilik algısı anketinde 5 açık uçlu soru yer almaktadır. Bu sorular "Eğitimde yenilikçilik (inovasyon) kavramını tanımlayınız", "Günümüzde inovasyona örnek veriniz", "Sizce yenilikçi öğretmenin özellikleri nelerdir?", "Öğretim materyali hazırlama ve oluşturmada yenilikçilik ne anlama gelmektedir? Örnek vererek açıklayınız" ve "Kendinizi öğretim materyali hazırlama ve oluşturmada ne derece yenilikçi görüyorsunuz? Nedenleriyle açıklayınız"dır.

Yenilikçi materyal hazırlamaya ilişkin öğretmen adayı günlükleri. Sınıf öğretmeni adaylarının her yenilikçi materyal geliştirme etkinliği sonrasında yenilikçi materyal geliştirme süreçlerini tanımlamaları, bu süreçte zorlandıkları, hoşlarına giden ya da gitmeyen noktaları paylaşmaları, geliştirdikleri materyallerin yenilikçi olma düzeyine ilişkin görüşlerini belirtmeleri istenmiştir. Öğretmen adaylarının görüşlerinin ayrıntılı olarak ortaya çıkarılması amacıyla öğretmen adayı günlüklerinde açık uçlu sorulara yer verilmiştir. Açık uçlu sorularla öğretmen adaylarının açıklayııı ve detaylı olarak görüşlerini ifade edecekleri düşünülmektedir. Hazırlanan soruların kapsam geçerliği ve görünüş geçerliği açısından değerlendirilmesi için eğitim programları ve öğretim alanında uzman iki araştırmacının görüşleri alınmış ve görüşler doğrultusunda gerekli düzeltmeler yapılmıştır.

\subsection{Veri Analizi Teknikleri}

Yenilikçilik eğitimi öncesi ve sonrasında kullanılan yenilikçilik algısı anketi ile öğretmen adayı günlüklerinin analizinde tümevarımsal içerik analizi yapılmıştır. Nitel verilerin analizi 4 aşamada gerçekleştirilmiştir. Bu aşamalar, verilerin kodlanması, temaların bulunması, kodların ve temaların düzenlenmesi, bulguların tanımlanması ve yorumlanmasıdır. Öncelikle öğretmen adaylarından elde edilen nitel veriler araştırmacılar tarafından defalarca okunarak verilerin anlamlandırılması sağlanmıştır. Araştırmacılar tarafından analiz edilen nitel verilere ilişkin tema ve kodlar oluşturulmuştur. Nvivo 8 programının temalara, kodlara, kodların referanslarına ve kaynaklarına ilişkin sunduğu raporlar Eğitim Programları ve Öğretim alanında uzman araştırmacıya incelemesi amacıyla verilmiş ve uzmandan görüş birliğinde ve görüş ayrılığında olduğu kodları belirtmesi istenmiştir. "Görüş birliği" ve "Görüş ayrılığı" olan kodların belirlenmesinin ardından Miles ve Huberman'ın (1994) güvenirlik formülü [Güvenirlik=Görüş Birliği/(Görüş Birliği+Görüş Ayrılığı)] kullanılarak yapılan kodlamanın güvenirliği hesaplanmıştır. Bireysel yenilikçilik ölçeği ön test ve sontest puanları arasında istatistiksel olarak anlamlı farklıığın olup olmadığının belirlenmesinde ilişkili örneklemler için t testi; cinsiyetin bireysel yenilikçilik ölçeğinden alınan puanların ortalamasında farklılaşma oluşturan bir değişken olup olmadığının belirlenmesinde ilişkisiz örneklemler için t testi kullanıımıştır. 


\subsection{Geçerlik ve Güvenirlik Çalışmaları}

Araştırmanın geçerliğini sağlamak için araştırmacının ortamda 11 hafta zaman geçirmesi sağlanarak çalışma grubuyla etkileşim süresi uzatılmış ve durumu daha uzun süre gözlemlemesi sağlanmıştır. Çalışmanın katılımcılarına ve öğretim sürecine ilişkin ayrıntılı açıklama yapılmıştır. Araştırmada öğretmen adaylarının yenilikçi materyal geliştirme süreçleri boyunca gözlem yapılması ve günlüklerin toplanması, işlem öncesi ve sonrasında yenilikçilik algısı anketi ve bireysel yenilikçilik ölçeğinin uygulanmasıyla veri çeşitlemesi yapılmıştır. Elde edilen verilerin geçerliği sağlamak için veri toplanan kişilerin görüşleri alıntı yapılarak çalışmada sunulmuştur. Yenilikçilik algısı anketine ilişkin eğitim programları ve öğretim alanı ile ölçme ve değerlendirme alanında uzman araştırmacıların görüşleri alınarak anket formunda gereken düzenlemeler yapılmıştır. Araştırmanın güvenirliği çalışma sürecinin açıkça betimlenmesiyle sağlanmaya çalışıımıştır. Ayrıca nitel veri analizinde nitel verilerin 2 ayrı kodlayıcı tarafından kodlanması ve kodlayıcılar arası güvenirlik analizi gerçekleştirilmesi çalışmanın güvenirliğini arttırdığı düşünülmektedir. Kodlayıcılar arası güvenirlik analiz, kodlayıcılar tarafından ortak ve ortak olmayan kodların belirlenmesi, Miles ve Hubermann'ın (1994) kodlayıcılar arası güvenirlik formülü kullanılarak gerçekleştirilmiştir. Uygulama öncesi toplanan nitel verilerin içerik analizine ilişkin kodlayıcılar arası güvenirlik değeri .81; uygulama sonrası toplanan nitel verilerin içerik analizine ilişkin güvenirlik değeri .85 bulunmuştur. Araştırmacıların kodlama güvenirliklerinin sağlanması için uyuşum yüzdesinin \%80'nin üzerinde olmasının yeterli olduğu belirtilmektedir (Miles ve Huberman, 1994).

\section{BULGULAR}

Ö Sınıf öğretmeni adayları tarafından geliştirilen yenilikçi kavram haritalarının yenilikçi olma durumu kavram haritasının üç boyutlu tasarlanması ve görselliğinin arttırılması olarak belirtilmiştir. Öğretmen adayları tarafından geliştirilen ve "Kavram Ağacı", "Kavram Çanı" olarak adlandırılan materyal görselleri aşağıda sunulmuştur:
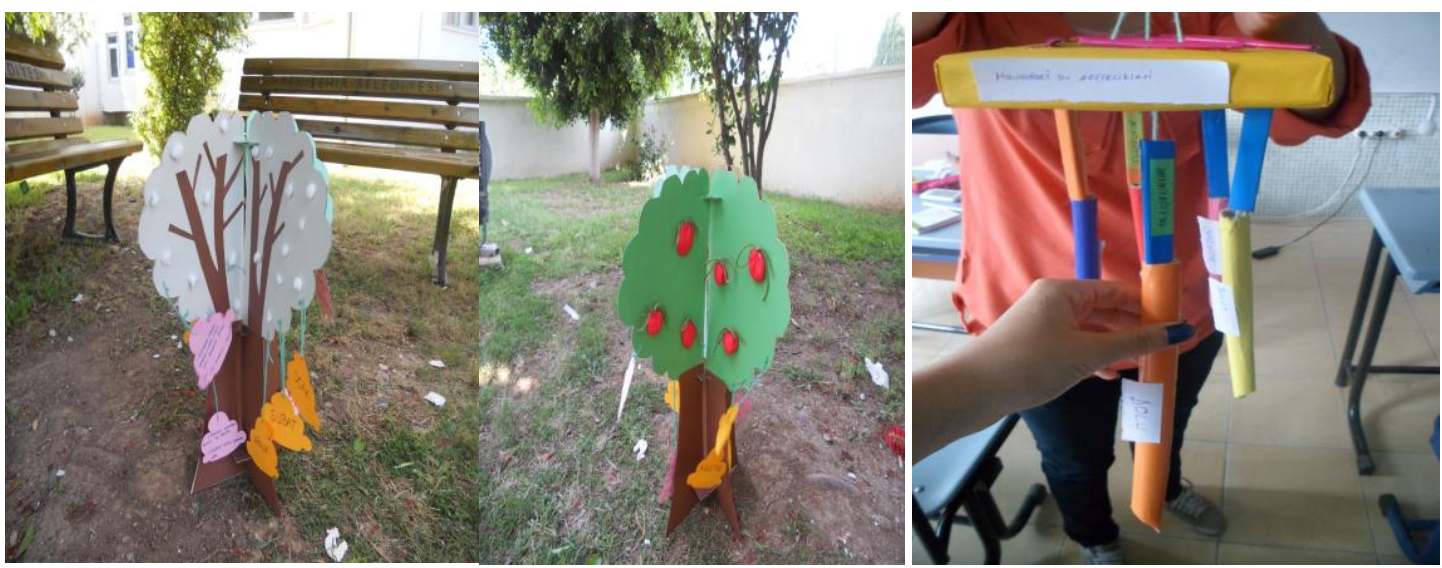

Görsel 1. Yenilikçi Kavram Haritası Örneği

Öğretmen adaylarının yenilikçi materyali geliştirme süreçlerinde zorlandıklarını ancak grup çalışmasının işlerini kolaylaştırdığını belirttikleri görülmüştür. Ayrıca kavram haritalarının yenilikçi olması, üç boyutlu olarak tasarlanmasıyla ilişkilendirilmiştir. Öğretmen adaylarının yenilikçi kavram haritası geliştirme süreçlerine ilişkin görüşlerine aşağıda yer verilmiştir:

"Yenilikçi öğretim materyali olarak kavram ağacı tasarladık. Bunun için mukavvadan üç boyutlu ağaç yaptık. Bez ve elişi kağıtları yardımı ile ağaç görüntüsü verdik. Yaptığımız materyalde mevsime göre belirlediğimiz meyveleri bölmeler oluşturduğumuz ağacımıza her mevsimi simgeleyecek şekilde taktık. Ayrıca o mevsime ait ayları renkli fon kağıtlarına yazıp ağacımıza taktık. Fon kağıtlarının arkasına o mevsimin özelliğini yazdık. Bu materyali oluştururken oldukça 
zorlandık. Ancak grup olarak yaptığımız görev dağılımı sayesinde herbirimiz ağacın bir bölümünü yaparak kavram haritasını kısa sürede tamamladık. Mevcut kavram haritalarına üç boyutlu olma ve sınıfın bir köşesine konularak öğrencinin dikkatini daha çok çekme ve zihinde canlandırmanın kolaylaşması açısından yenilik getirdiğimizi düşünüyoruz." (Grup 1)

"Ders kitaplarında anlatılan konuları üç boyutlu hale getirip, sıkıcılığı ortadan akılda kalıcılığını arttırdığımız için geliştirdiğimiz materyalin yenilikçi olduğunu düşünüyoruz." (Grup 3)

"Kavram haritasının kağıt üzerine çizmek yerine üç boyutlu olarak tasarlamak bir yeniliktir." (Grup 4)

Sınıf öğretmeni adayları tarafından geliştirilen yenilikçi çalışma yapraklarının yenilikçi olma durumu grupla oyun etkinliği olarak tasarlanması ve üç boyutlu olmasıyla ilişkilendirilmiştir. Öğretmen adayları tarafından geliştirilen yenilikçi çalışma yaprağı örneklerine aşağıda yer verilmiştir:
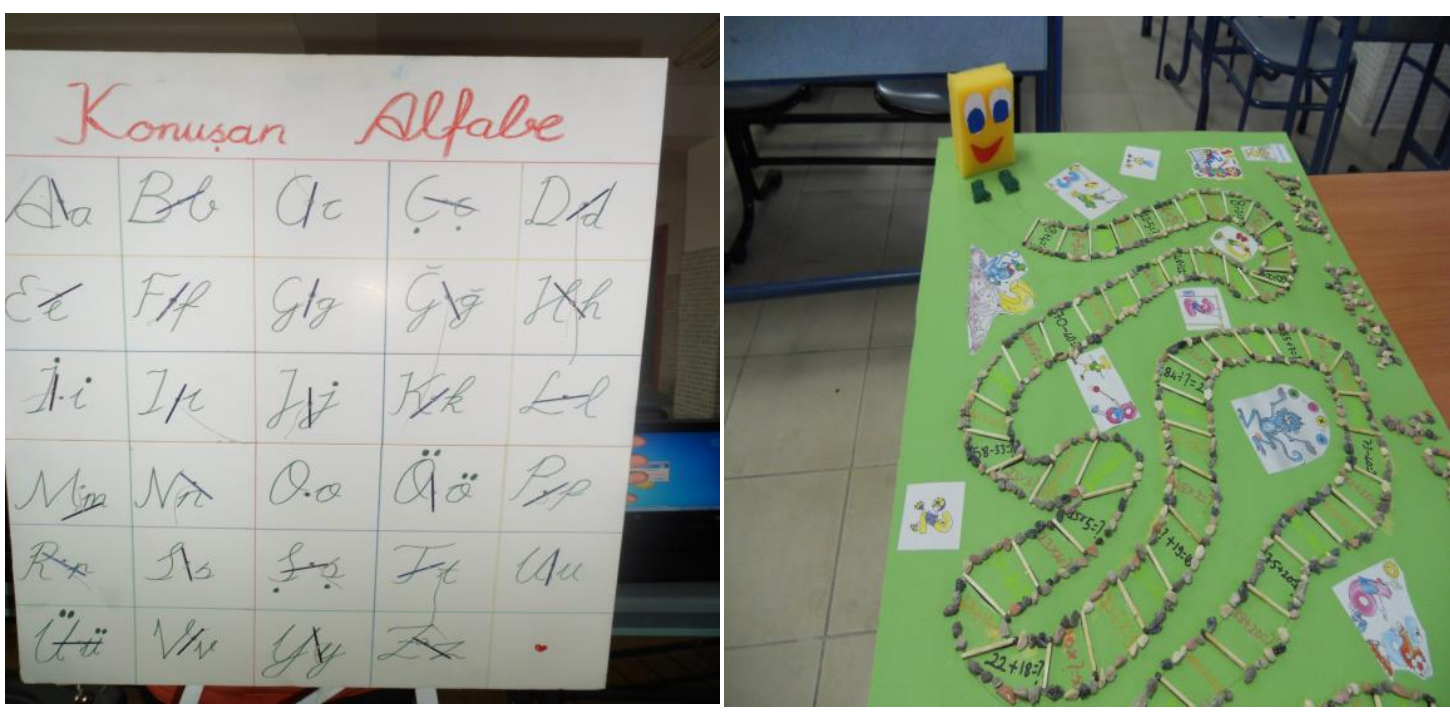

Görsel 2. Yenilikçi Çalışma Yaprağı Örneği

Öğretmen adaylarının yenilikçi çalışma yaprağı geliştirme süreçlerine ilişkin görüşlerine aşağıda yer verilmiştir:

"Yenilikçi olarak alfabeye zil sesi ekledik. Konuyla ilişkili olarak sesli harflerde ses çıkarmak için zil taktık, sessiz harflerde ise ses oluşturmadık. Böylece klasik alfabe öğretimini sesli ve ilgi çekici hale getirdik. Yenilikçi materyal olarak ne tasarlayabiliriz sorusunun cevabını bulmada yani düşünme aşamasında zorlandık. Karar verdikten sonra materyali geliştirme sürecini kolaylıkla başardık ve grupla çalışmamızda çok eğlendik." (Grup 2)

“Çalışma kağıdı olarak bulmaca ve oyun hazırladık. Bu materyali tasarlama amacımız, öğrencileri eğlendirerek öğrenmelerini sağlamaktır. Klasik çalışma kağıtlarının dışında bu materyalle bireyselliği bir kenara bırakıp çalışmayı sınıf ortamına taşıyarak grup çalışmalarını özendirmek amaçlanmıştır. Çalışma yaprağını bireysellikten çıkarıp grup çalışması haline getirdiği için materyalin yenilikçi olduğunu düşünüyoruz." (Grup 5)

"ilk defa yenilikçi bir materyal hazırlayacağımız için neler yapacağımız konusunda sorun yaşadık. İçeriğin eğlenceli olması ise materyal hazırlama sürecinde eğlendiğimiz noktalardı. Materyal geliştirme sürecinde grupla çalışmamız bazı arkadaşlarımızla samimiyetimizi arttırmış ve insanları daha yakından tanımamızı sağlamıştır." (Grup 5)

Sınıf öğretmeni adayları tarafından geliştirilen yenilikçi üç boyutlu materyallerin yenilikçi olma durumu materyalin yaşamda kullanılabilir olması ve görselliğinin arttırılmasıyla 
ilişkilendirilmiştir. Ayrıca materyal geliştirme sürecinde işbirliği içinde çalışmanın yenilikçi fikirlerin ortaya çıkışını kolaylaştırdığı yönünde görüşler bulunmaktadır. Aşă̆ıda öğretmen adayları tarafından tasarlanan yenilikçi üç boyutlu materyal görselleri ile yenilikçi üç boyutlu materyal geliştirme süreçlerine ilişkin görüşlerine yer verilmiştir:
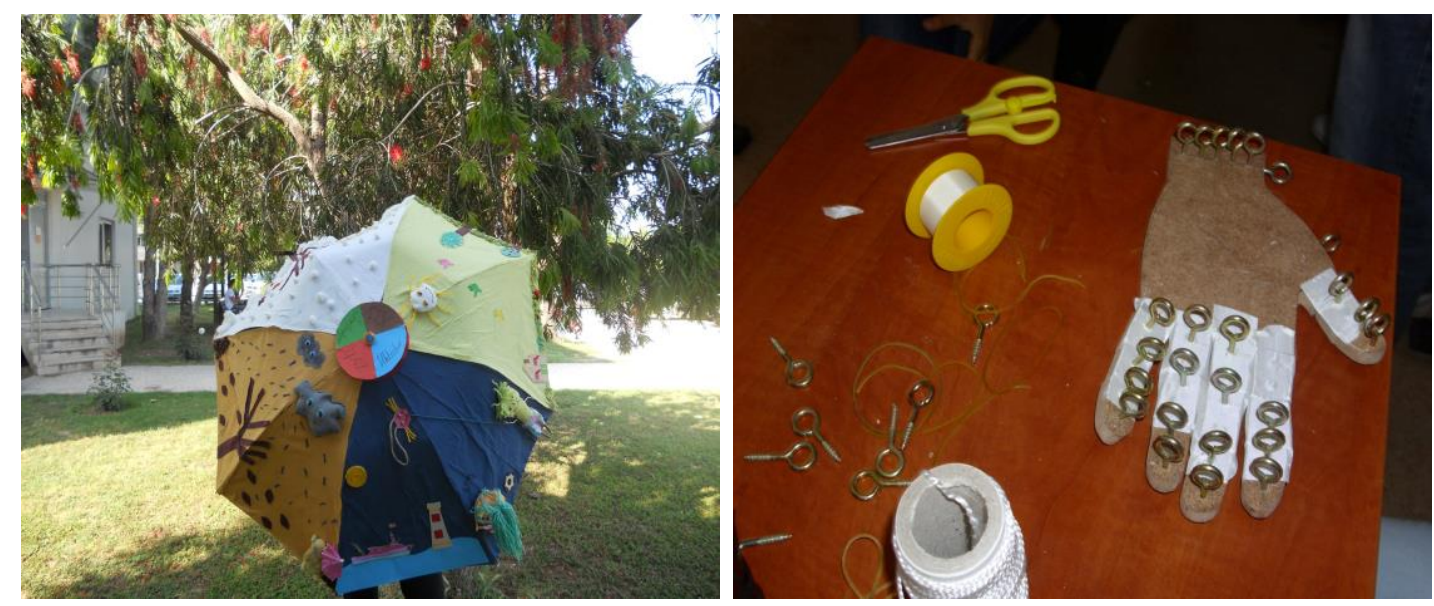

Görsel 3. Yenilikçi Üç Boyutlu Materyal Örneği

"Bir şemsiyenin üstüne mevsimlere uygun renkteki bezler yapıştırdık. Daha sonra her mevsime özgü nesneleri şemsiyenin üzerine yapıştırdık. Daha sonra şemsiyenin üstüne dört mevsimi yazdığımız bir çark yerleştirdik. Şemsiyenin öğrencilerin günlük yaşamında kullandıkları bir nesne olması nedeniyle öğretim materyalinin sınıf ortamının dışına çıkarak öğrencinin yaşamında yer alması sağlanmıştır. Bu nedenle bu materyalin yenilikçi materyal olma özelliği taşıdığını düşünüyoruz." (Grup 2)

“Materyalin tasarlanma sürecinde grupla çalışmak farklı görüşlerin ortaya çıkmasını sağlamaktadır. Böylece nasıl bir materyal geliştireceğimiz konusunda karar vermemiz kolaylaşmıştır." (Grup 3)

Sınıf öğretmeni adaylarının yenilikçi mateyal geliştirme süreçlerine ilişkin görüşleri dikkate alındığında, öğretmen adaylarının yenilikçilik kavramını algıladıklarını, yenilikçi materyal tasarlarken materyal geliştirme ilkelerini dikkate aldıklarını, kaynakları değerlendirerek iş planı yaptıklarını ve grup üyelerinin bu plana uyduğunu, mevcut materyallere yenilik getirdiklerini, fikir üretme aşamasında zorlandıkları ancak hiçbir zaman yılmadıklarını, tüm fırsatları değerlendirerek yenilikçi materyal (ürün) ortaya koyabildiklerini, yenilikçi materyal tasarlamanın kendilerine farkıı bakış açısı sağladığı ve bundan çok memnun olduklarını, grup üyeleriyle çalışmanın işlerini kolaylaştırdığını ve sorumluluk aldıklarını, yapamayacakları herhangi birşeyin olmadığı bilincine sahip olduklarını, gruplar arasında birinci olmak için ellerinden gelenin ötesinde çaba harcadıklarını, başarıya odaklandıklarını ve yenilikçi materyal ürettiklerini belirttikleri görülmüştür. Her gruptan kendi materyalini yenilikçi olma düzeyine göre öz değerlendirme yapması istendiğinde öğretmen adaylarının kendi materyallerine 90 ile 100 aralığında puan verdikleri ve materyallerinin yenilikçi olduğu yönünde görüş belirttikleri görülmektedir.

Sınıf öğretmeni adaylarının yenilikçilik ölçeğinden elde ettikleri puanların ortalaması öntest ve son test arasında anlamlı bir farklılık olup olmadığının belirlenmesi için gerçekleştirilen ilişkili örneklemler için $t$ testi sonuçları Tablo 1'de sunulmuştur: 
Tablo 1.

Sınıf Öğretmeni Adaylarının Yenilikçilik Düzeylerine Ilişkin Algıları-iliş̧kili Örneklemler Iç̧in T Testi Sonuçları

\begin{tabular}{lcccccc}
\hline Yenilikçilik & $\mathbf{N}$ & $\overline{\mathrm{X}}$ & SS & sd & $\mathbf{T}$ & $\mathbf{p}$ \\
\hline Ön test & 27 & 58,60 & 6,39 & 26 & 4,810 & .000 \\
Son test & 27 & 69 & 8,82 & & & \\
\hline
\end{tabular}

Sınıf öğretmeni adaylarının yenilikçilik ölçeği ön test puanlarının evrendeki dağıımın normal olması nedeniyle $\left(S-W_{27}=.965, p>.05\right)$ gerçekleştirilen ilişkili örneklemler için t testi sonuçları incelendiğinde, sınıf öğretmen adaylarının yenilikçilik düzeylerinin son test uygulamalarının lehine anlamlı fark çıktığı görülmektedir. Sınıf öğretmeni adaylarının yenilikçilik düzeylerine ilişkin algılarının cinsiyete göre farklıık gösterip göstermediğinin belirlenmesi için gerçekleştirilen ilişkisiz örneklemler için $t$ testi sonuçları Tablo 2'de sunulmuştur.

Tablo 2.

Sınıf Öğretmeni Adaylarının Cinsiyete Göre Yenilikçilik Düzeylerine Illişkin Algıları-ilişkisiz Örneklemler Iç̧in TTesti Sonuçları

\begin{tabular}{llccccc}
\hline Yenilikçilik & $\mathbf{N}$ & $\overline{\mathrm{X}}$ & SS & sd & $\mathbf{T}$ & $\mathbf{p}$ \\
\hline Kadın & 17 & 66,50 & 7,71 & 26 & 1,616 & .124 \\
Erkek & 10 & 72,75 & 9,54 & & & \\
\hline
\end{tabular}

Tablo 2'ye göre, sınıf öğretmeni adaylarının yenilikçilik düzeylerine ilişkin algılarının cinsiyete göre farklılık göstermediği görülmektedir. Erkek öğretmen adaylarının yenilikçilik düzeylerine ilişkin algılarının ortalaması 72,75; kadın öğretmen adaylarının yenilikçilik düzeylerine ilişkin algılarının ortalaması ise 66,50 'dir. Kadın ve erkek öğretmen adaylarının yenilikçilik düzeyleri ortalamaları arasında gözlenen farklılığın istatistiksel olarak anlamlı olmadığı saptanmıştır. Erkek ve kadın sınıf öğretmeni adaylarının benzer yenilikçilik algılarına sahip olmaları, karma eğitimin kadın ve erkeklere aynı öğrenme ortamlarından yararlanma fırsatı sunması açısından önemini göstermektedir. Aynı öğrenme ortamlarında öğrenme imkanı bulan kadın ve erkeklerin benzer becerileri benzer düzeyde kazanmalarını kolaylaştırdığı düşünülmektedir.

Sınıf öğretmeni adaylarının yenilikçi materyal tasarlama süreci öncesi ve sonrası yenilikçilik kavramına ilişkin algılarının ortaya çıkarılması ve yenilikçi materyal tasarlamanın öğretmen adaylarının yenilikçilik algılarında farklılaşma oluşturup oluşturmadığının saptanması amacıyla gerçekleştirilen nitel veri analizi sonuçlarına Şekil 2 ile Şekil 3 'te yer verilmiştir: 


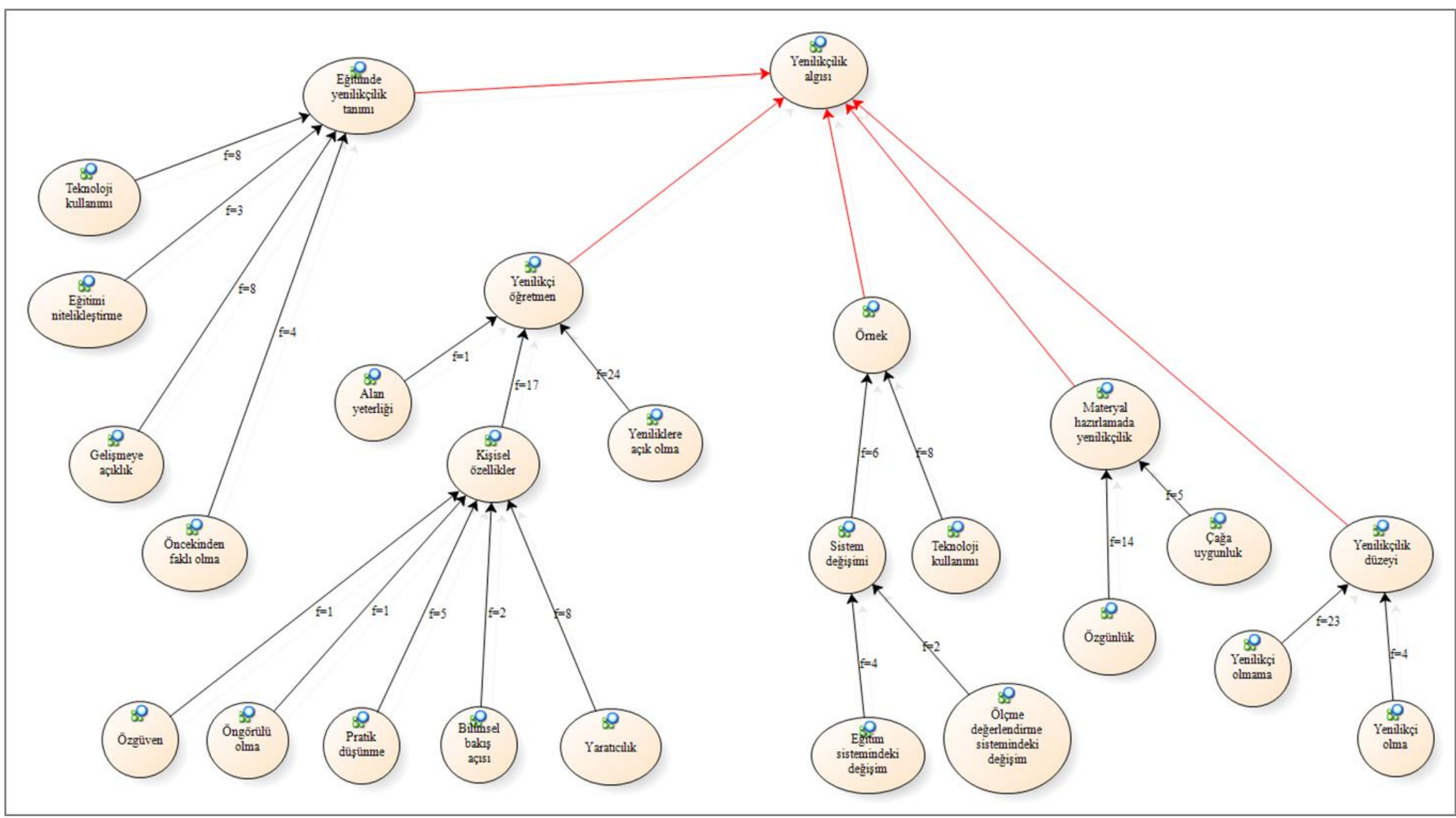

Şekil 2. Öğretmen Adaylarının Yenilikçi Materyal Tasarlama Öncesi Yenilikçilik Algısı 


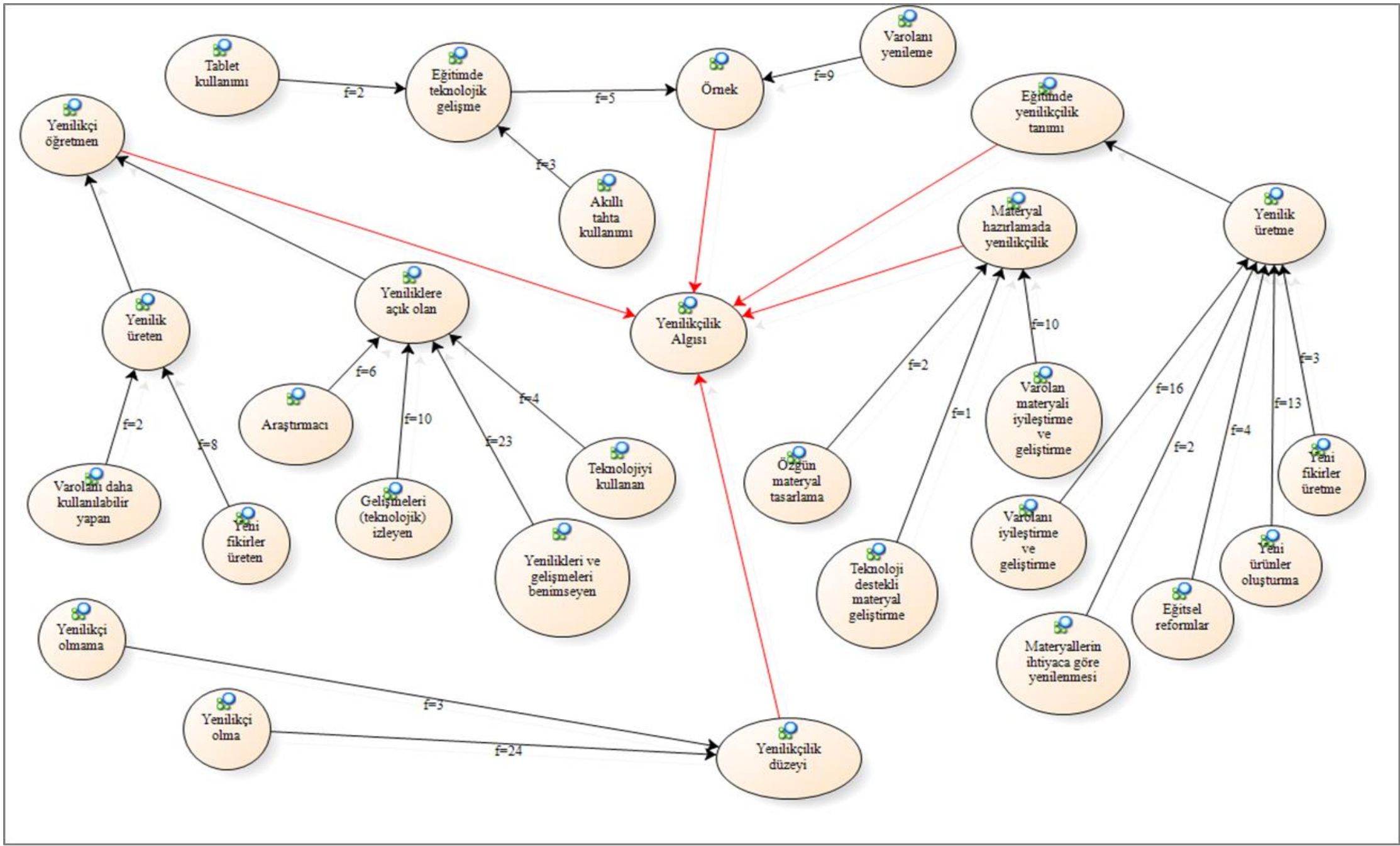

Şekil 3. Öğretmen Adaylarının Yenilikçi Materyal Tasarlama Sonrası Yenilikçilik Algısı 
Sınıf öğretmeni adaylarının yenilikçi materyal geliştirmeden önce eğitimde yenilikçilik kavramına ilişkin algıları "gelişmeye açıklık", "teknoloji kullanımı", "öncekinden farklı olma" ve "eğitimi nitelikleştirme" olarak sınıflandırılırken, materyal geliştirme süreci sonrası eğitimde yenilikçilik kavramına ilişkin algıları "yenilik üretme" olarak tek kategoride toplanmıştır. Eğitimde yenilikçilik kavramı; yenilik üretmek temasında, yeni ürünler oluşturma $(f=13)$, varolan sistemi ve ürünü geliştirme $(f=16)$, yeni fikirler geliştirme $(f=3)$, materyallerin ihtiyaca göre yenilenmesi $(f=2)$ ve çağa uygun eğitim reformlarının yapılması $(f=4)$ kodlarıyla açıklanmıştır. Sınıf öğretmeni adaylarının eğitimde yenilikçilik kavramına ilişkin algılarının "yenilik üretme" olarak tek kategoride toplanmasıyla yenilikçi materyal tasarlama sürecinin öğretmen adaylarının yenilik kavramına ilişkin algılarının üretme boyutuna odaklandığı düşünülmektedir. Bu bağlamda öğretmen adaylarının yenilikçi materyal geliştirme süreci sonrasında yeni ürün, hizmet, fikir ya da uygulama ortaya koydukları algısına sahip oldukları düşünülebilir. Ayrıca öğretmen adaylarının uygulama süreci sonrasında yenilikçilik kavramını "yenilik üretme" olarak tek kategoride açıklamış olmaları, öğretmen adaylarının yenilikçilik kavramına ilişkin hemfikir olduklarını göstermektedir. Sınıf öğretmeni adaylarının eğitimde yenilikçilik kavramına ilişkin görüşlerinden bazılarına aşağıda yer verilmiştir.

\footnotetext{
"Eğitimde yenilikçilik mevcut bir nesnenin ya da bir uygulamanın üstüne farklı bir şeyler yaparak yeni bir ürün ya da uygulama ortaya koymaktır." (öğretmen adayı 7)

"Yenilikçilik, varolana yeni birşeyler katma, iyileştirme ve intiyaçlara yanıt verir hale getirmektir." (öğretmen adayı 11).

"Eğitimde yenilikçilik, varolan sistemi geliştirmektir." (öğretmen adayı 17)

"Yenilikçilik, reform demektir. Bir başka deyişle, varolan birşeyi iyileştirmektir." (öğretmen adayı 19)
}

"Eğitimde yenilikçilik, varolan eğitim sistemini yeniliklere açık tutmak ve geliştirmek." (öğretmen adayı 21)

Yenilikçi öğretim materyali tasarlama sürecinden önce sınıf öğretmeni adaylarının yenilik kavramına ilişkin verdikleri örneklerin sistem değişimi ve teknoloji kullanımı kategorilerinde açıklandığı görülmektedir. Bu bağlamda öğretmen adaylarının yeniliği eğitim sistemindeki değişimler, ölçme ve değerlendirme sistemindeki değişimler ve teknolojik uygulamalarla ilişkilendirdikleri görülmektedir. Yenilikçi öğretim materyali tasarlayan öğretmen adaylarının yenilikçilik kavramına yönelik verdikleri örnekleri teknoloji kullanımı ve varolanı yenileme kategorilerinde açıkladıkları görülmektedir. Öğretmen adaylarının yenilikçilik algısında teknolojinin yenilikçiliğin ayrılmaz bir parçası olduğu görülmektedir ve herhangi bir ürün, hizmet, bilgi ya da uygulamanın yenilenme sürecinde olmasının yenilikçilik kavramıyla ilişkilendirildiği görülmektedir.

Sınıf öğretmeni adayları yenilikçi öğretmeninin sahip olması gereken özellikleri yenilikçi materyal tasarlama süreci öncesinde kişisel özellikler, yeniliklere açık olma ve alan yeterliği olarak tanımlamaktadırlar. Ancak yenilikçi materyal tasarlama sürecinden sonra yenilikçi öğretmenin sahip olması gereken özelliklerin yeniliklere açık olma ve yenilik üretme olarak tanımlandığı gözlenmektedir. Yenilikçi materyal tasarlama sürecinden sonra öğretmen adayları yenilikçi öğretmeni yeniliklere ve değişime açık olan, teknolojik gelişmeleri izleyen, araştırma yapan, gelişmeleri izleyen, teknolojiyi kullanan, yeni fikirler üreten ve var olanı kullanılabilir yapan olarak betimlemişlerdir. Sınıf öğretmeni adaylarının yenilikçi öğretmenin özelliklerine ilişkin görüşlerinden bazılarına aşağıda yer verilmiştir:

"Yenilikçi öğretmen yaratıcı düşünceye sahip olmalıdır. Çağımızdaki yeniliklere ayak uydurmalı ve araştırmacı olmalıdır." (öğretmen adayı 13) 
"Yenilikçi öğretmen eğitim sistemindeki yeni uygulamaları bilen ve nasıl uygulanacağını öğrenmeye çalışandır." (öğretmen adayı 15)

"Yenilikçi öğretmen yeniliklere açık olan, eğitim alanındaki yenilikleri izleyen ve öğretim materyali ya da öğretim yaklaşımlarına yenilik getirendir." (öğretmen adayı 24)

Sınıf öğretmeni adayları materyal hazırlamada yenilikçiliği mevcut öğretim materyalini iyileştirme, geliştirme, teknolojiyle bütünleştirme ve özgün materyal tasarlama olarak tanımlamışlardır. Sınıf öğretmeni adaylarının materyal tasarlamada yenilikçiliğe ilişkin görüşlerinden bazıları aşağıda sunulmuştur.

"Var olan bir şeyi günümüz teknolojisiyle birleştirip daha işe yarar hale getirmektir." (öğretmen adayı 3)

"Var olan bir materyalin daha kullanılabilir hale getirilmesi ve daha fazla ihtiyaca cevap verecek şekilde düzenlenmesi." (öğretmen adayı 11)

"Kullanılan araç gereçleri, bilgileri geliştirmeye yönelik tasarımlar yenilikçilik örneğidir. Yenilikçi materyal var olan materyalin daha geliştirilmiş tasarımıdır." (öğretmen adayı 13)

“Mevcut materyale farklılık ve yenilik kazandırmaktır." (öğretmen adayı 14)

"Olmayan özgün bir materyal tasarlamaktır." (öğretmen adayı 15)

"Var olan materyali yaratı bir şekilde geliştirmektir." (öğretmen adayı 16)

"Var olan materyale özgün nitelikler yüklemektir. Değişik fikirlerle o materyali geliştirmek ve kullanışı hale getirmektir." (öğretmen adayı 25)

Yenilikçi öğretim materyali tasarlama sürecinden önce sınıf öğretmeni adaylarının çoğunlukla kendilerinin yenilikçi olmadığı yönünde görüş belirttikleri görülmüştür. Öğretmen adaylarının yeterince yenilikçi olmadığına yönelik öz değerlendirmelerini destekleyen kodlardan bazıları şöyledir: "Yenilikçi değilim ( $f=15)$ ", "Yenilikleri takip etmem ( $f=3)$ ", "Hayal gücüm zayıf $(f=1)$ ", "Eğitim sistemi yenilikçi olmamızı engelliyor $(f=1)$ ", "Yaratıcı değilim $(f=1)$ ". Yenilikçi öğretim materyali tasarlama sürecinden sonra ise, sınıf öğretmeni adaylarının kendilerini yeterince yenilikçi gördükleri saptanmıştır. Öğretmen adaylarının yenilikçi olduklarına ilişkin görüşlerini destekleyen öğretmen adayı ifadelerinden bazılarına aşağıda yer verilmiştir:

“Ben eski öğretim yöntemleriyle beraber yeni yöntemlerin denenmesinden yanayım. Yani eski yöntemleri tamamıyla kaybetmeyip onları iyileştirerek ve geliştirerek yeniden yapılandırmak gereklidir. Bu konuda kendimi yeterli görüyorum." (öğretmen adayı 7)

“Öğretim materyali tasarlama ve oluşturma konusunda yenilikçi olduğumu düşünüyorum. Materyal dersinde hazırladığımız materyallerden sonra kendimi yenilikçilik konusunda geliştirdiğime inanıyorum." (öğretmen adayı 13)

"Yeniliklere açığım." (öğretmen adayı 19)

"Yeni ürünler oluşturmak mutluluk verici." (öğretmen adayı 22)

“Inovatif materyal tasarladım.” (öğretmen adayı 27)

Özetle, sınıf öğretmeni adaylarının ön test uygulamalarında yenilikçilik kavramına yükledikleri anlamda farklılaşma olurken ve yenilikçilik kavramına ilişkin yüzeysel tanımlamalar yaptıkları saptanmışken, son test uygulamalarında yenilikçilik kavramına yüklenen anlamların homojenleştiği ve yenilikçilik kavramını tüm boyutlarıyla algıladıkları görülmektedir. Ayrıca yenilikçi materyal tasarlama süreci öncesinde yenilikçi materyal tasarlama konusunda yenilikçi olmadıklarına ilişkin öğretmen adayı algılarının yenilikçi materyal tasarlama uygulamaları sonrasında olumlu yönde değiştiği gözlenmektedir. 


\section{SONUÇ, TARTIŞMA VE ÖNERILER}

Yenilikçilik ölçeği ön test ve son test ölçümleri arasında istatistiksel olarak anlamlı bir farklılığın saptanmasına dayanarak grupla yenilikçi materyal geliştirmenin sınıf öğretmeni adaylarının yenilikçilik düzeylerinde artışı sağladığı yargısına ulaşılabilir. Yenilikçi materyal hazırlama süreci sonrasında sınıf öğretmeni adaylarının yenilikçilik kavramını öğrendiklerini, yenilikçi materyal tasarlarken materyal geliştirme ilkelerini dikkate aldıklarını, kaynakları değerlendirerek iş planı yaptıklarını ve grup üyelerinin bu plana uyduğunu, mevcut materyallere yenilik getirdiklerini, fikir üretme aşamasında zorlandıklarını ancak hiçbir zaman yılmadıklarını, tüm fırsatları değerlendirerek yenilikçi materyal (ürün) ortaya koyabildiklerini, ellerindeki kaynakları kullanarak yenilik getirici materyaller tasarlayabildiklerini, yenilikçi materyal tasarlamanın kendilerine farklı bakış açısı sağladığını ve bundan çok memnun olduklarını, mevcut materyallerin dışında yenilik getiren materyaller tasarlamaktan zevk aldıklarını, grup üyeleriyle çalışmanın işlerini kolaylaştırdı̆̆ını ve sorumluluk aldıklarını, en yenilikçi materyali tasarlamak için ellerinden gelenin ötesinde çaba harcadıklarını, başarıya odaklandıklarını ve inovasyon ürettiklerini belirttikleri görülmüştür. Bu doğrultuda özgün olma ve yenilik üretme fırsatı tanınan öğretmen adaylarının yenilikçilik düzeylerinde artışın olabileceği yargısına varılabilir. Bu sonuç birçok araştırmacının öğretmen eğitiminde yenilikçi uygulamaların arttırılmasına yönelik önerilerini ortaya çıkarmıştır. Örneğin, yenilikçi düşünen birey modelini sunan Özmusul (2012) öğretmen yetiştiren kurumlarda öğretmen adaylarında inovasyon algısının oluşturulmasına, öğretmen adaylarının yaratıcı ve yenilikçi öğretim sürecine dahil olmalarına vurgu yapmıştır. Fidan (2015) da eğitim fakültelerindeki inovatif uygulamaların öğretmen adaylarına mesleki bilgi, beceri ve değerler kazandırmadaki etkisini vurgulayarak öğretim elemanlarının öğretim süreçlerinde inovatif uygulamalara yer vermeleri gerektiğini vurgulamıştır. Şahin, Bilgili ve Kocalar (2015) da eğitim ve yenilikçilik kavramlarının birbiriyle ilişkili olduklarını vurgulayarak, eğitim yoluyla bireylerin yenilikçilik düzeylerinin gelişebileceğini ve yenilikçiliğe yönelik olumlu tutum geliştirebileceklerini eklemiştir. Tüm bu çalışmalar doğrultusunda yenilikçi birey kimliğinin oluşturulmasında yenilikçi eğitim uygulamalarının önem taşıdığı sonucuna ulaşılabilir.

Sınıf öğretmeni adaylarının yenilikçi materyal geliştirmeden önce eğitimde yenilikçilik kavramına ilişkin algıları "gelişmeye açıklık", "teknoloji kullanımı", "öncekinden farklı olma" ve "eğitimi nitelikleştirme" olarak sınıflandırılırken, yenilikçi materyal geliştirme süreci sonrası eğitimde yenilikçilik kavramına ilişkin algıları "yenilik üretme" olarak tek kategoride toplanmıştır. Sınıf öğretmeni adaylarının eğitimde yenilikçilik kavramına ilişkin algılarının "yenilik üretmek" olarak tek kategoride toplanmasıyla yenilikçi materyal tasarlama sürecinin öğretmen adaylarının yenilik kavramına ilişkin algılarının üretme boyutuna odaklandığı düşünülmektedir. Bu bağlamda öğretmen adaylarının yenilikçi materyal geliştirme süreci sonrasında yeni ürün, hizmet, fikir ya da uygulama ortaya koydukları algısına sahip oldukları düşünülebilir. Ayrıca öğretmen adaylarının uygulama süreci sonrasında yenilikçilik kavramını "yenilik üretme" olarak tek kategoride açıklamış olmaları, öğretmen adaylarının yenilikçilik kavramına ilişkin hemfikir olduklarını göstermektedir.

Yenilikçi öğretim materyali tasarlayan öğretmen adaylarının yenilikçilik kavramına yönelik verdikleri örnekleri teknoloji kullanımı ve var olanı yenileme kategorilerinde açıkladıkları görülmektedir. Öğretmen adaylarının yenilikçilik algısında teknolojinin yenilikçiliğin ayrılmaz bir parçası olduğu görülmektedir ve herhangi bir ürün, hizmet, bilgi ya da uygulamanın yenilenme sürecinde olmasının yenilikçilik kavramıyla ilişkilendirildiği görülmektedir.

Yenilikçi materyal tasarlama sürecinden sonra öğretmen adaylarının yenilikçi öğretmenin yeniliklere ve değişime açık olan, teknolojik gelişmeleri izleyen, araştırma yapan, teknolojiyi kullanan, yeni fikirler üreten ve var olanı kullanılabilir yapan olarak algıladıkları 
yargısına varılabilir. Bu bağlamda sınıf öğretmeni adaylarında yenilikçi öğretmen algısının oluşturulduğu ve yenilikçi olma durumu açısından öz değerlendirme yapabilecekleri ve öz değerlendirme sonucunda elde ettikleri bilgiler doğrultusunda kendilerini geliştirebilecekleri düşünülebilir. Grunberg ve Summer (1992) ile Mumtaz (2000) eğitsel deneyimin Drent ve Meelissen (2008) ise kişisel girişimciliğin yenilikçi öğretim uygulamalarına yer verilmesini önemli ölçüde arttırdığını vurgulamışlardır. Bu çalışmalar bağlamında kişisel girişimcilik, yansıtıcı ve araştırma temelli tutuma sahip olmayla ilişkilendirilmiştir. Öğretmen adaylarına yenilikçi öğretim materyali tasarlama ve değerlendirme fırsatı verilmesiyle öğretmen adaylarının kişisel girişimcilikleri desteklenerek ve onlara eğitsel deneyim kazandırılarak öğretmen adaylarının yenilikçi öğretim uygulamalarına olumlu algı geliştirmelerinin sağlandığı düşünülebilir.

Sınıf öğretmeni adayları materyal hazırlamada yenilikçiliği mevcut öğretim materyalini iyileştirme, geliştirme, teknolojiyle bütünleştirme ve özgün materyal tasarlama olarak tanımlamışlardır. Bu bulguya dayanarak sınıf öğretmeni adaylarının yenilikçilik kavramını özelleştirerek materyal geliştirme sürecinde yenilikçiliğin ne anlama geldiğine yönelik algılarının oluştuğu yargısına varılabilir. Ayrıca yenilikçi materyal tasarlama süreci öncesinde yenilikçi materyal tasarlama konusunda yenilikçi olmadıklarına ilişkin öğretmen adayı algılarının yenilikçi materyal tasarlama uygulamaları sonrasında olumlu yönde değiştiği sonucuna varılabilir. Bu sonuçlar; inovasyonu destekleyen yaklaşımla düzenlenen eğitim uygulamalarıyla bireylerin yenilikçiliğe ilişkin olumlu algı geliştirmelerinin ve yenilikçi bireyler olmalarının sağlanabileceğini göstermektedir. Bu nedenle, yenilikçi bireyler yetiştirecek öğretmen adaylarında yenilikçi öğretmen kimliği oluşturmak için öğrenimleri süresince yenilikçi projeler üretebilmeleri sağlanmalıdır. Bu bağlamda öğretmen adaylarının öğrenme sürecini tasarlayan öğretim elemanlarının yenilikçi olmaları, teknoloji temelli yenilikçi öğretim uygulamalarıyla ve yenilikçi fikirleriyle öğretmen adaylarının vizyonlarını geliştirmeleri önemli görülmektedir. Öğretmen adaylarının Eğitim Fakültelerinde materyal tasarımcısı gibi eğitilmeleri gerekmektedir. Tasarım aslında yenilik üretmeyi gerektirmektedir. Materyal tasarımcısı olarak öğretmen adaylarının yenilikçi birey kimliğine sahip olmaları önemlidir. Bu nedenle öğretmen adaylarının yenilikçi olmaları, çağın getirdiği yeniliklere direnç göstermemeleri ve özellikle de eğitim alanındaki yenilikleri kolaylıkla kabullenmelerini sağlamak için öğretmen adaylarının yaratıcı olabileceği, özür düşünerek yeni değerler, ürünler ve projeler üretebileceği ve eğitim alanındaki yeniliklerle karşılaşabilecekleri öğrenme ortamları tasarlanmalıdır. Ayrıca öğretmen adaylarının ürettikleri yenilikçi fikir ya da ürünlere ilişkin öz değerlendirme yapmaları sağlanarak, yenilikçi kimliklerine ilişkin algılarının oluşması gerçekleştirilebilir. Yükseköğretim kurumlarında eğitim uygulamaları deneyime dönük, araştırmayı, bilimsel ve özgün düşünmeyi gerekli kılan ve inovasyonu destekleyecek biçimde tasarlanmalıdır. 


\section{KAYNAKLAR}

Aksay, K. (2011). Yenilikçilik kültürünün örgütsel yenilikçilik üzerine etkisi: Konya ilinde faaliyet gösteren özel hastanelerde bir uygulama. (Yayımlanmamış Doktora Tezi). Selçuk Üniversitesi, Konya.

Basadur, M. ve Gelade, G. A. (2006). The role of knowledge management in the innovation process. Creativity and Innovation Management, 15(1), 45-62.

Cohen, D. K. ve Ball, D. L. (2000). Instructional innovation: Reconsidering the story. Ann Arbor: University of Michigan, The Study of Instructional Improvement.

Çelik, M. (2006). Ilköğretim okullarında değişimin ve yeniliklerin uygulanmasını engelleyen faktörlerin öğretmen ve yönetici algılarına göre belirlenmesi. (Yayınlanmamış Yüksek Lisans Tezi), Gaziantep Üniversitesi, Gaziantep.

Çoklar, A. N. (2012). Individual innovativeness levels of educational administrators. Digital Education Review, (22), 101-110.

Çuhadar, C., Bülbül, T. ve Ilgaz, G. (2013). Öğretmen adaylarının bireysel yenilikçilik özellikleri ile teknopedagojik eğitim yeterlikleri arasındaki ilişkinin incelenmesi. ilköğretim Online, 12(3).

Davey, L. (1991). The application of case study evaluations. ERIC Clearinghouse on Tests, Measurement, and Evaluation. http://eric.ed.gov/?id=ED338706 (Erişim Tarihi: 2016, 30 Eylül).

Demirel, Y. ve Seçkin, Z. (2008). Bilgi ve bilgi paylaşımının yenilikçilik üzerine etkileri. Ç.Ü. Sosyal Bilimler Enstitüsü Dergisi, 17(1), 189-202.

Drent, M. ve Meelissen, M. (2008). Which factors obstruct or stimulate teacher educators to use ICT innovatively? Computers \& Education, 51, 187-199.

Elçi, Ş. (2005). Eski köye yeni adet getirin! www.focusinnovation.net/Download/ekin_tanitim.pdf. (Erişim Tarihi: 2011, 15 Nisan).

Elçi, Ş. (2011). Gelecek için eğitim programları ve politikaları. TED (Ed.), Uluslararası eğitim forumu II: Eğitimde inovasyon içinde (69-73), Ankara: İşkur Matbaacılık Kağ. San. ve Tic. Ltd. Şti.

Erdal, M. (2001). Yeni bin yılda girişimci eğitiminin önemi. TOSYÖV Girişim Dergisi, 4-5.

Erdoğan, D. G. ve Güneş, D. Z. (2013). The relationship between individual innovatiness and change readiness conditions of students attending faculty of education. Procedia-Social and Behavioral Sciences, 106, 3033-3040.

Ersoy, B. A. ve Şengül, C. M. (2008). Yenilikçiliğe yönelik devlet uygulamaları ve AB karşılaştırması. Yönetim ve Ekonomi. Celal Bayar Üniversitesi Iktisadi ve Idari Bilimler Fakültesi Dergisi, 15(1), 59-74.

Fidan, M. (2015). Akademisyenlerin sınıflarında örgütsel değer yönetimi düzeyleri ve öğretim sürecinde inovatif uygulamaları. Bartın Üniversitesi Eğitim Fakültesi Dergisi, 4(1), 151-162.

Goldsmith, R. E. ve Foxall, G. P. (2003). The measurement of innovativeness. L.V. Shavinina (Ed.), The international handbook of innovation içinde (s.321-329). Oxford: Elsevier Sciences Ltd.

Grunberg, J., \& Summers, M. (1992). Computer innovation in schools: A review of selected research literature. Journal of Information Technology for Teacher Education, 1(2), 255-276.

Hurt, H. T., Joseph, K. ve Cook, C. D. (1977). Scales for the measurement of innovativeness. Human Communication Research. 4, 58-65

Kılıçer, K. (2011). Bilgisayar ve öğretim teknolojileri eğitimi öğretmen adaylarının bireysel yenilikçilik profilleri. (Yayınlanmamış Doktora Tezi). Anadolu Üniversitesi, Eskişehir. 
Kılıçer, K. \& Odabaşı, F. H. (2010). Bireysel yenilikçilik ölçei (BYÖ): Türkçeye uyarlama, geçerlik ve güvenirlik çalışması. Hacettepe Üniversitesi Eğitim Fakültesi Dergisi (H. U. Journal of Education), 38, 150-164.

Lope Pihie, Z. A. \& Bagherı, A. (2011). Are teachers qualified to teach enterpreneurship? Analysis of enterpreneurial attitude and self-efficacy. Journal of Applied Sciences, 11(18), 3308-3314

Luecke, R. (2008). İş dünyasında yenilik ve yaratıcılık. (Çev.: Turan Parlak), Türkiye İş Bankası Kültür Yayınları, Yayın: 1387, İstanbul.

Mcmillan, H. J. ve Schumacher, S. (2010). Research in education. Boston: Pearson Education.

Miles, M. B. ve Huberman, A. M. (1994). Qualitative data analysis: An expanded sourcebook, 2nd Ed. Thousand Oaks: Sage.

Mumtaz, S. (2000). Factors affecting teachers' use of information and communication technology: A review of the literature. Journal of Information Technology for Teacher Education, 9(3), 319-341.

Özmusul, M. (2012). Öğretmen eğitiminde yaratıcılık ve inovasyon. Kastamonu Eğitim Dergisi, 20(3), 731-746.

Öztürk, Z. Y. ve Summak, M. S. (2014). Illköğretim öğretmenlerinin bireysel yenilikçiliklerinin incelenmesi. International Journal of Science Culture and Sport, 1, 844-853.

Partnership for 21st Century Skills. (2005). Learning for the 21st century: A report and mile guide for 21st century skills. http://www.21stcenturyskills.org/images/stories/otherdocs/P21_Report.pdf. (Erişim Tarihi: 2016, 18 Mayıs).

Romer, P. (2007). Türkiye inovasyonla nasıl kalkınacak. Türkiye 2. Inovasyon Konferansı içinde (s. 93-108). İstanbul: Turkishtime.

Şahin, V., Bilgili, M. ve Kocalar, A.O. (2015). Coğrafya lisans öğrencilerinin eğitimdeki inovasyon ile ilgili görüşleri. Turkish Studies, 10(11), 1411-1426.

Tella, S. ve Kirsi, T. (1999). An Analysis of the aims and outcomes of "the European observatory" of the European Commission (1994-1998). Research Report 200.

Yıldırım, A. ve Şimşek, H. (2006). Sosyal bilimlerde nitel araştırma yöntemleri (6.baskı). Ankara: Seçkin Yayıncılık.

Yılmaz, M. (2007). Sınıf öğretmeni yetiştirmede teknoloji eğitimi. Gazi Üniversitesi Gazi Eğitim Fakültesi Dergisi, 27(1).

WEF (2015). The Global Competitiveness Report 2014-2015 (Full Data Edition). World Economic Forum.

Wolpert, J. D. (2003). Yenilik Kutularının Dışına Çıkmak, Yenilikçilik, (Çev. Ahmet Kardam). İstanbul: MESS Yayınları. 


\section{SUMMARY}

The mutual determining effect between innovativeness and education necessiates that they should be reorganized in educational settings in order to increase their quality. At first glance, teachers as implementators of education service should be ready for acceptting innovations, accept innovations easily in a short time, not resist to innovation, in other words they should possess innovative identity. Therefore, this study aims to help pre-service teachers to have innovative identity by providing them opportunities for creating innovative materials. In accordance with this purpose, following questions are attempted to be answered in this study:

1. What are the perceptions of elementary school pre-service teachers related to their innovativeness level after innovative material design process?

1.1. Is there a statistically significant difference between innovativeness levels of elementary school pre-service teachers before and after innovative material design process?

1.2. Do innovativeness levels of elementary school preservice teachers differentiate depending on gender after innovative material design process?

2. What are the perceptions of elementary school pre-service teachers related to innovativeness before and after innovative material design process?

The study, having been carried out to determine the effects of designing innovative material on the elementary school prospective teachers' innovativeness and present their perceptions on innovativeness after the process of designing innovative material, was designed as a case study. Research group consisted of 27 third pre-service teachers educated at Elementary School Teaching Program at Mersin University during 2013-2014 academic year. Individual innovativeness scale and innovativeness perception questionaire were applied to the pre-service teachers before and after the process of designing innovative materials. Moreover, they kept diaries about the design of innovative materials. Content analysis was conducted for the analysis of qualitative data by using Nvivo Program. Quantitative data was analyzed through such techniques as descriptive statictics, t-test for dependent and independent samples.

As a result of the study, it was found out that there is an increase in the innovativeness level of the elementary school pre-service teachers desinging innovative material. Considering the statistical significant difference between pre-test and post-test results of innovativeness scale, it is possible to state that innovative material development as a group increases innovativeness level of pre-service teachers. In this study, following findings emerged: elementary school pre-service teachers learned the concept of innovativeness during process of innovative material design, they considered material development principles while designing innovative material, they created plan of action by evaluating sources and group members acted in accordance with plan, they brought innovativeness to the current materials, however, they had difficulty with generating ideas but they never gave up, they evaluated all possibilities for innovative material development, they used avaliable sources and designed innovative materials. Also, pre-service elementary teachers claimed that innovative material design process supplied them different points of view and they really enjoyed this, they got pleasure while designing innovative materials not being obliged to current materials.

The perceptions of pre-service elementary teachers related to innovativeness in education before innovative material design process can be categorized as "openness to development", "technology usage", "being different from the previous ones" and "qualifying education". After innovative material design process, their perceptions of innvativeness in education are categorized in one theme as "generating innovativon". Innovativeness in education is explained in "generating innovation" theme with the following codes: generating new products $(f=13)$, developing current system and product $(f=16)$, generating new ideas $(f=3)$, renewing materials in accordance with needs $(f=2)$, making modern educational reforms $(f=4)$.

Elemantary school pre-service teachers define characteristics of innovative teachers as personal qualities, opennes to innovations and specific area competences. After innovative material design process, elemantary school pre-service teachers describe innovative teacher as "openness to innovation 
and change, following technological developments, conducting research, monitoring developments, using technology, generating new ideas and making the avaliable ones usable". Elementary school preservice teachers define innovativeness in material development as "improving the avaliable instruction material, developing and integrating it into technology and designing authentic material. Considering this finding, it is possible to state that elementary school pre-service teachers customized innovativeness concept and developed a perception about what innovativeness mean in material development process. Also, before inovative material development design process, pre-service teachers perception of themselves was negative related to innovativeness in material development but it changed in a positive way after material design process. These findings indicate that instruction practices organized by considering innovation contribute to individuals' developing positive perceptions about innovativeness and to their self-improvement as innovative people. 